\title{
Çariçe Anna Zamanında Rusya'nın Karadeniz Politikası
}

Sinan YÜKSEL

Öz: Ruslar, IV. İvan ve I. Petro dönemlerinde Karadeniz'e çıkmak adına önemli adımlar atmışlarsa da bunu başaramadılar. Bununla birlikte Rusya'nın doğal yayılma sahası içinde bulunan Karadeniz'e çıkma isteği bir hedef olarak onlardan sonra gelen Çar ve Çariçeler tarafından da devam ettirildi. 1730 Ocak'ında Rus tahtına çıkan Çariçe Anna'da Karadeniz devleti olma adına önemli çalışmalar yaptı. Öncelikli olarak güney bölgelerinin güvenliği sorununu ele alan Çariçe Anna, Rus ordusunun sayısını artırıp, Ukrayna topraklarında savunma hatları yaptırdı. Bunun yanı sıra Zaporojye Kazaklarını himayesine alan Çariçe Anna, diplomatik olarak da İngiltere, Avusturya, Lehistan, İran ve İsveç ile dostluk anlaşmaları yaptı.

Bu dönemde Osmanlı Devleti, Rusya'nın kendisine karşı askerî hazırlıklar içerisinde olmasını bilmesine rağmen, Rusya'ya karşı barış politikasını değiștirmedi. Osmanlı Padişahı I. Mahmud, Kırım Hanına Rus topraklarına saldırılmaması, zarar verilmemesi yönünde emirler verirken, Rusya 1735'te, Kırım Hanının, Kııım, Rusya ve Osmanlı Devleti arasında sahipliği tartışmalı olan ama Rusya'nın kendi toprakları olarak kabul ettiği, Kabartay üzerinden Rus sınırlarını ihlal etmesini savaş nedeni sayarak Kırım Hanlığına savaş açtı. 1736 ile 1739 yılları arasında yapılan Rus-Osmanlı savaşında Ruslar askerî anlamda başarılar kazansa da, Karadeniz devleti olma hayalini gerçekleştiremedi. Bununla birlikte Rusya, Çariçe Anna zamanında savaş öncesindeki güney sınırlarını güven altına alma ve Karadeniz'de ticaret yapma düşüncesini kısmen de olsa gerçekleştirmiş oldu.

Anahtar Kelimler: Osmanlı Devleti, Rusya, Çariçe Anna, Karadeniz, Kırım Hanlığı.

\footnotetext{
Bu çalıșma Sinan Yüksel'in “Rusların Karadeniz Devleti Olma Süreci ve Bu Süreçte Rus-Osmanlı ilişkileri”, Ankara Üniversitesi, Sosyal Bilimler Enstitüsü, Ankara 2011, basılmamış doktora çalışmasından genişletilerek üretilmiștir. Yrd. Doç. Dr., Bülent Ecevit Üniversitesi, Fen Edebiyat Fakültesi, Tarih Bölümü, sinanyksel@yahoo.com.
} 


\title{
The Policy of Russia in Black Sea During The Reign of Tsarina Anna (1730-1740)
}

\begin{abstract}
Despite the fact that the Russians have taken significant steps to exit the Black sea during the reign of Ivan the 4th, and Peter the 1st, they failed. The aim of the Russians to enter the Black sea also continued, and the subsequent tsars and tsarinas. Tsarina Anna, ascended the throne in January 1730 , had important work to become the Black sea state. Initially, the Tsarina Anna considered the security problem in southern areas and by increasing the strength of the Russian army, created the defensive line on the Ukrainian lands. For this she took under the protection of the Zaporozhe Cossacks, and concluded friendly diplomatic agreements with England, Austria, Poland, Iran and Sweden.

During this period, the Ottoman state despite its awareness of the preparation of Russia to military action against the Ottoman Empire, continued to pursue a Russia-friendly policy. Despite the fact that the Ottoman Sultan Mahmud the 1st, ordered the Crimean Khan not to attack Russian soil and not to harm them, and in 1735 Russia started the war against the Crimean Khanate, considering the reason for war, the violation of Russian borders in Kabardin, which Russia considered its territory.

Despite the fact that in the 1736-1739 war between Russia and the Ottoman Empire, the Russians achieved victory, their dream of becoming the black sea state did not materialize. Along with this, during the reign of Tsarina Anna Russia was partly ensured the security of the southern borders and trade on the Black sea.
\end{abstract}

Keywords: Ottoman State, Russia, Tsarina Anna, Black Sea, Khanate.

Karadeniz, Rusya'nın kalbinden inen suların yani Don ve Dinyeper nehirlerinin döküldüğü, Rusya'nın iç ticaretinin dayandığı nehir nakliyle dışarıya açılmasına imkân sunan bir denizdir. Rusya'nın Karadeniz'e hâkim olma isteği politik, ekonomik ve askerî nedenlere dayanıyordu. Rusya için Karadeniz'e çıkış ekonomik anlamda büyümeyi sağlayacağı gibi politik ve askerî anlamda da önemli kazanımlar sağlayabilirdi (Melnikova, 1948: 77). Bunun farkında olan Rus devlet adamları Altınordu egemenliğinden çıkıp iç sorunlarını hallettikten hemen sonra Karadeniz yönünde genişlemek için faaliyetlere başladılar. Ruslar, IV. İvan ve I. Petro dönemlerinde Karadeniz'e çıkma adına önemli adımlar atmışlarsa da bunu başaramadılar (Yüksel, 2013: 101-116; Yüksel, 2012: 171-190). Bununla birlikte Rusya'nın doğal yayılma sahası içinde Karadeniz'e çıkma bir hedef olarak onlardan sonra gelen çar ve çariçeler tarafından da devam ettirildi. Bu anlamda Petro'dan sonra Karadeniz'e yönelik en önemli hazırlıklar Çariçe Anna zamanında yapıldı. Ocak 1730'da Rus tahtına çıkan Çariçe Anna tahta çıkar çıkmaz Karadeniz yönünde önemli hazırlıklar yapmaya başladı.

Çariçe Anna öncelikli olarak güney bölgelerinin güvenliği sorununu ele aldı. Kırım Tatarları tarafından 1725 ile 1735 yılları arasında Poltova ve Mirgorod'daki alay birlikleriyle, Bahmut, Kafkasya, Don ve Ukrayna'daki diğger bölgelere saldırılar yapılmaktaydı. Devamlı saldırı tehdidinden dolayı Rusya, 
güneyde büyük askerî birlikler bulundurmak zorunda kalıyordu. Sürekli saldırı tehdidini ortadan kaldırmanın yanı sıra Rusya'nın Doğulu ve Batılı devletlerle olan ticareti için de güneyde güvenliğin sağlanması ve Karadeniz'deki pozisyonunu güçlendirmesi gerekiyordu. Bu sorunun çözümlenmesi için Rusya, XVIII. yüzyılın 30'lu yıllarının başından itibaren askerî tedbirler almaya başlayıp, uzun ve titiz diplomatik bir hazırlığın içine girdi (Kazakov, Nekrasov, 1957: 365; Nekrasov, 1976: 74-75, 244.).

Askerî tedbir olarak; 1731'de gerçekleştirilen askerî-organizasyon faaliyetlerinden sonra Rus ordusunun sayısı 129 bine ulaştı (Kazakov, Nekrasov, 1957: 374). 1731 ile 1735 yılları arasında, Dinyeper Nehri ile Kuzey Don Nehri arasında güçlendirilmiş Ukrayna hattı yapıldı. Daha sonra bir ucu Poltova ve Kharkov illeri ile diğer ucu ise neredeyse güçlendirilmiş Ann hattına kadar uzanan Ekaterinoslav ili arasında bir hat daha yapıldı. Bu hat boyunca 20 milis alayı yerleştirildi. Don Nehri'nin ağzında Çariçe Anna'nın adıyla onurlandırılan, Aziz Ann adında yeni bir kale inşa edildi (Vernadsky, 1936: 244). Güney sınırlarının güvenliği için önemli olan bu savunma hatlarının inşaatında çok sayıda insan çalıştırıldı. Bu insanların önemli bir kısmı Kazaklardan oluşuyordu. Kazak Hetmanı (Hatmanı) ${ }^{1}$ Apostol çalışacak işçi sayısının giderek artması üzerine Çariçe Anna'ya bir mektup yazarak, Ukrayna'da gerçekleşen askerî hazırlıkların çok ağır olduğunu belirtip, “... eğer bu şartlarda, böylesine kıtlıkta 30 bin kişi daha gönderirsek, hatlardaki yoğunluk her iki tarafa yani bize ve büyük devletinize zararlı olacaktır. Çünkü böylece askerî hazırlıklar, yemek ve diğer kaynakların hazırlanması gecikir" diyerek, hat için gönderilecek kişi sayısının yarıya kadar indirilmesini rica etti. Apostol'un ricası senatoda ve hattın inşası için tüm işlere bakan savaş heyeti tarafından tartışıldı. Hetman haklı bulundu. Osmanlı Devleti ile yapılacak olan savaşta kaynakların tükenmesi ve işe yaramaz hale gelmesi ihtimali işleri zora sokabilirdi. Bundan dolayı Çariçe Anna 25 Mart 1733'de Hetman'a yazdığı cevapta, sayıyı 30 bin kişiden 10 bin kişiye indirdiğini belirtti. Fakat Anna, bu kişilerin bu işe uygun olanlardan seçilmesini, yani yaşlı veya çok genç insanlardan oluşmamasını ve gelenlerin malzemeleriyle birlikte gelmelerini istedi. Çariçe Anna, hatlarda çalışan işçilerin kaçmamaları için de gerekli olan tedbirlerin alınmasını emretti (Melnikova, 1948: 80).

Askerî birliklerin yiyecek ve diğer gerekli ihtiyaçlarının karşılanması için de önemli hazırlıklar yapıldı. Petro tarafından Osmanlı Devleti ile olası bir savaş için Ukrayna'nın güneyindeki bazı stratejik bölgelerde temelleri atılan kaynaklar kullanılamaz durumdaydı. 1732 yılında bölgeye incelemeler yapmak için gelen General Keyt, kaynakların özensiz bir şekilde muhafaza edilmesinden dolayı bozulduğu ve çürüdüğünü görerek, bir rapor hazırladı. Raporda Petro zamanında oluşturulan ambarların boş olduğu ve ancak Ukrayna'dan alınacak ekmekle doldurulabileceğini yazdı. Ekmeklerin bir kısmının Rus köylerinden (büyük bir

\footnotetext{
Hetman (Hatman): Eski Türk toplulukları ve özelikle de Lehistan ile Ukrayna Kazaklarında başkumandanlara verilen bir unvan. (Nagıyev, 1997: 484)
} 
kısmı Tombovskaya'dan) bir kısmının ise peşin parayla Ukrayna köylerindeki pazarlardan alınması kararlaştırıldı (Melnikova, 1948: 81).

Rusya bu dönemde Zaporojye Kazaklarını himayesine almak adına da çalışmalar yürüttü. Rus Hükümeti, Zaporojye Kazaklarına, onların ihtiyaçlarını karşılayacağı, suçlarını affedeceği, onları Rus sınırları içerisine alacağı yönünde yazılar gönderdi. Rusya'nın böyle davranmasında Zaporojye Kazaklarını askerî bir güç olarak kullanma düşüncesinin yanı sıra Lehistan, Kırım Hanlığı ve Osmanlı Devleti'nin yardımıyla güçlendirilip, Kırım Hanı ile Rus topraklarına saldırma tehlikesini ortadan kaldırma düşüncesinin de önemli bir yeri vardı. Kendisine Zaporojye Kazaklarıyla ilgili fikri sorulan İstanbul'daki Rus elçisi Nepluyev de Çariçe'ye onları hemen himayesi altına almayı önerdi. Nepluyev, Çariçe’ye yazmış olduğu mektupta şunları yazdı: “... Eğer Rusya onları koruması altına almayı kabul etmezse Osmanlı Devleti onları kendi silahı olarak kullanacaktır. Ayrıca Zaporojye Kazaklarını himayesi altına almaz ve onlara verdiği sözleri yerine getirmezse Ukrayna halkı da hayal kırıklığına uğrayacak ve Kırım Hanından yardım isteyeceklerdir". Rusya ile Zoporojye Kazakları arasında yapılan görüşmeler sonrasında Kazaklar, Rus topraklarına geçmeyi ve Rusya ile Osmanlı Devleti arasında barış bozulursa Rusya'nın yanında savaşa girmeyi kabul ettiler. İstanbul'a bir mektup gönderilerek, Nepluyev'e Osmanlı Devleti'nden Zaporojye Kazakları ile ilgili bir soru geldiğinde, şu şekilde yanıt vermesi istendi: Zaporojye Kazaklarının uzun yıllardan beri Rusya himayesinde yaşadıklarını, Kırım tarafında yaşamaya başladıklarında ise Rusya'nın buna karışmadığını ve müdahalede bulunmadığını, Kazakların Kırım Hanı'nın davranışlarından memnun kalmayarak Rus topraklarına geçmeye karar verdiklerini belirtmesi istendi (Melnikova, 1948: 82).

Rusya bu askerî hazırlıkların yanı sıra, diplomatik hazırlık olarak da; 1720’li yıllarda i̇stanbul'da Rusya aleyhtarı bir politika izleyen ve Osmanlı Devleti'ni Rusya'ya karşı savaşa teşvik eden İngiltere ile 1734 yılında ticari bir anlaşma yapılarak bir yakınlaşma sağlandı (Vernadsky, 1936: 243; Nekrasov, 1976: 244.).

1726'da Avusturya ile yapılan ittifak antlaşması 1732'de yenilendi ve 1733'de Lehistan tahtı için yapılan mücadelede Fransa'ya karşı birlikte hareket edildi. Avusturya'nın da desteğiyle Lehistan tahtına çıkarılan III. August'la, Lehistan ile dostluk kuruldu. İran ile 1729, 1732 ve 1735 yıllarında yapılan antlaşmalarla, Petro döneminde Hazar bölgesinde ele geçirilen ve önemli sayıda Rus birliklerini meşgul eden topraklardan vazgeçilerek, İran ile birlikte Osmanlı Devleti'ne karşı ittifak yapıldı. Yine bu dönemde Danimarka ile yakınlaşıldı. İsveç ile 1724'te kurulan ittifak 5 Ağustos 1735'te yenilendi (Nekrasov, 1976: 80). ${ }^{2}$

\footnotetext{
Bu suretle 1730 'lu yıllarda Rusya'nın tek engeli olarak Fransa kaldı. 1720 ve 1730 'lu yıllarda Fransa diplomasisi, Osmanlı Sultanını ve İsveç'i Rusya’ya karşı silahlı mücadeleye girmesi için kışkırtıyordu. Fransa özellikle Lehistan'daki taht mücadelesinde yaşamış olduğu başarısızıktan sonra, Lehistan'da kaybettiği konumu geri alabilmek ve Rusya'nın Karadeniz'de güçlenmesini engellemek için “Doğu Bariyeri” propagandasına başladı. Bu politikanın amacı, Rusya'ya düșman ülkelerden bir birlik oluşturarak Rusya'nın Avrupa'ya açılan yollarına "bariyer” kurmaktı. Fransızlar bu bariyere, uç noktalarını oluşturan İsveç ve Osmanlı Devleti dışında, Prusya ve Lehistan'ın
} 
Böylece Rusya, uzun bir diplomatik hazırlık sonrasında, güney probleminin çözümünü mümkün kılacak elverişli bir uluslararası ortam hazırladı. ${ }^{3}$

Bu dönemde İstanbul'da bulunan Rus elçileri İ. Nepluyev ve A. Veşnyakov da Petersburg'a gönderdikleri raporlarında Osmanlı Devleti'ne karşı savaş çağrılarında bulunuyorlardı. Osmanlı Devleti ile çıkan anlaşmazlıklarda Rusya'nın çıkarlarını korumakla birlikte Osmanlı Devleti'nin askerî ve politik durumunu yakından takip edip rapor sunmakla görevli olan elçiler, Petersburg'a gönderdikleri raporlarında Osmanlı Devleti'nin yaşadığı ağır iç sorunlar ve İran ile yapmış olduğu savaş yüzünden, Rusya'ya karşı hemen bir savaşı başlatma gücünde olmadığını rapor ediyorlardı. Elçiler raporlarında ayrıca Osmanlı Devleti'nin içinde bulunduğu durum nedeniyle açılacak savaşta Rusya'nın kazancının sadece güney sınırlarının güvenliğini sağlamakla sınırlı kalmayacağını belirtiyorlardı. Elçilerin düşüncelerine göre, Rus ordularının Dinyester ve Tuna'ya yapacakları seferler sırasında Balkan yarımadası halkları da Rus ordularını destekleyecekler ve sonuçta köküne kadar çürümüş olan Osmanlı Devleti parçalanacaktı. Elçilerin gönderdikleri raporlarda "Osmanlıların kökünü kazıma”, "Petro'nun düşüncelerini gerçekleştirme”, "Rusya için o kadar elverişli koşulların 100 yıl sonra da tekrar gelmeyebileceği” şeklinde ifadeler yer alıyordu. E. B. Şulman'ın da ifade ettiği gibi elçilerin değerlendirmelerinde doğruluklar olduğu gibi olayları abarttıkları da görülüyordu. Elçilerin savaş çağrılarına rağmen Rusya, yukarıda anlatılan hazırlıkları tamamlayana kadar Osmanlı Devleti'ne karşı barış politikasını 1735 yılına kadar değiştirmedi (Şulman, 1963: 10-16). ${ }^{4}$

Bu dönemde Osmanlı Devleti, Rusya'nın kendisine karşı askerî hazırlıklar içerisinde olmasını bilmesine rağmen ${ }^{5}$ Rusya'ya karşı barış politikası izlemekteydi. Bu politikanın izlenmesinde İran ile yapılan mücadelenin önemli bir etkisinin olduğunu belirtmek gerekir. I. Mahmud, Kırım Hanı Kaplan Giray’a gönderdiği mektupta, Kalgay Sultan'ın bir miktar Tatar askerîyle Kabartay'a harekâtı sırasında, Moskov Devleti'nin sınırlarında olan general ve askerlerinden sınırlarımıza barışa aykırı bir saldırı gelmezse, Kaplan Giray’dan Moskov

da katılması için diplomatik faaliyetlerde bulunmuşlardır. Fransa'nın “doğu bariyeri” politikası, yükselişleri ve düşüşleriyle 1789 devrimine kadar sürdü. Bu bariyer asla Rusya'nın önünde sağlam ve sarsılmayacak bir engel olmadı. İsveç ve Prusya birkaç kez yer değiștirdiler, Lehistan ise genellikle Rusya'nın yanında yer aldı. (Sanin, 1999: 44-45)

3 Bu hazırlıların yapılmasında en önemli rolü Baron Osterman oynadı. Çariçe Anna'nın tahta çıkışından sonra, Rusya'nın siyasetinde en etkili kişi olan Osterman’a göre, Rus diplomasisinin en önemli görevi Karadeniz'e bağlantı kurmaktı. Bunun için gerekli diplomatik hazırlıkların yapılmasının yanı sıra, Petro'nun gerekli hazırlığı yapmadan Balkanlara doğru ilerleyişi yanlışının tekrarlanmaması gerektiğine inanıyordu. (Bkz. Vernadsky, 1936: 243-244)

4 Hazırlıklar tamamlandıktan sonra Rus Hükümeti, Kiev bölgesi valisi Kont Weissbach’a gönderdiği gizli emirle daha önce emredilen Kırım seferinin yanı sıra sonbaharda Azak Kalesinin de kuşatılmasını istedi. Ayrıca 1735 Ağustos'unda Lehistan'da bulunan Feldmareşal Münnich'e yazılan emirle de gizlice Don Nehri bölgesine gelerek Azak'ı kuşatmasını istendi. (Tertecel, 2002: 60-61)

5 1732'de İsveç'e elçi olarak gönderilen Said Mehmet Efendi dönüşünde Lehistan'a uğramış, Lehistan başvekili Ponyatovski veda toplantısında Said Mehmet Efendi'ye, Moskovluya güven olmayacağını, tek düşüncelerinin Azak ve Kırım'ı almak olduğunu, ansızın Azak'a saldırabileceklerini, bir an önce Azak'ı tamir edip, cephane ve zahire takviyesi yapmaya özen gösterilmesi gerektiğini söylemiştir. Said Mehmet Efendi Eylül 1733’te İstanbul’a dönmüştür. (Hocl, 659; 677) 
sınırlarına, zerre kadar bile zarar vermemesini istedi (Cebecioğlu, Satar, Küçükbaltacıoğlu, Atik, Dilber, Yekeler, Köse, Gurulkan, Gündoğdu, 2013: 25-26).

I. Mahmud Kırım Hanı'na göndermiş olduğu mektuplarda, İran seferine katılmasını istediği Kırım Hanı'ndan, Rus arazisinden uzak yerlerde konaklamasını, Ruslardan barışa aykırı olarak Tatarlara saldırı olmadıkça Rusların bir karış toprağına ve ferdine saldırmamasını ve yanındakilere de bu yönde tembihte bulunmasını istedi (Cebecioğlu, Satar, Küçükbaltacıoğlu, Atik, Dilber, Yekeler, Köse, Gurulkan, Gündoğdu, 2013: 40). Ayrıca Sadrazam Ali Paşa, Rus başvekili Osterman'a Kırım Hanı'nın Dağıstan yoluyla İran'a sefere gideceğini, Hanın bu seferine Osmanlı egemenliğine girmek isteyen Müslüman Dağıstan halkının da katılacağını, bu sefer sırasında Ruslardan bir saldırı olmazsa Kırım Hanı'na Rus topraklarına zarar vermemeleri yönünde emirler verildiğini bildirdi (Başbakanlık Osmanlı Arşivi (BOA), Name-i Hümayun (A.DVNS.NMH.d), c. 7: 393). Mektuba cevaben Osterman, Sadrazam Ali Paşa'ya şunları yazdı. Gelen mektubun içeriğine dair Çariçe’ye bilgi verdiğini, Rusya'nın Osmanlı Devleti ile daha önce yapılan anlaşmalara sadık kaldığını, bunun Osmanlı tarafından da bilindiğini, Osmanlı Devleti'nin Kırım Hanı'nın Dağıstan yoluyla, Dağıstan halkını itaat altına alıp, İran'a sefer yapması konusunda acele karar verdiğini ve bu durumun Çariçe tarafından hayretle karşılandığını bildirdi. Ardından Osmanlı reayasına kabul olunacak olan Dağıstan halkının eskiden beri Moskov Devleti'nin reayaları olduklarını, İran Devleti'nin dahi bugüne değin bura halkı için bir iddiada bulunmadığını, Osmanlı Devleti'nin de Dağıstan halkına alaka göstermesinin doğru olmadığını, bazı reayanın Osmanlı egemenliğini istemiş olabileceğini ama dost bir devlet olarak Osmanlı Devleti'nin onları himaye altına almak istemesinin doğru olmadığını yazdı. Ayrıca 1729 senesinde Sadrazam İbrahim Paşa zamanında Osmanlıdan yine himaye isteyen bazı Dağıstan halklarının bulunduğunu ama bunların isteklerinin kabul edilmediğini, hatta buna dair sadrazamın mektup gönderdiğini, Osmanlı Devleti ile Moskova Devleti arasında daha önce İran üzerine yapılan anlaşmada Osmanlı sınırlarının Şirvan eyaletinden öteye uzanmadığını, bundan dolayı da Dağıstan halklarına karışmasının doğru olmadığını ifade etti. Üstelik Çariçenin, Osmanlı Devleti ve İran ile yapılan anlaşmalara dostluk gereği uyarak, Osmanlı Devleti ile İran arasındaki savaşta bir tarafı tutmayarak tarafsız kaldığını, İran ile yapılan barış anlaşmasında Hazar kıyısındaki Şirvan toprakları İran'a verilmekle birlikte Dağıstan halkı eskiden beri Moskov reayası olduklarından bunlara dair İran ile hiç bir görüşme olmadığını bildirdi. Son olarak Çariçenin, Osmanlı Devleti'nin barışa aykırı olarak düşünmeden aldığı kararı değiştirmesi ve Hanın Tatar askerleriyle yapacağı seferi iptal etmesini umut ettiğini, bu sefer harekâtının her iki devletinde menfaatine aykırı olduğunu, buna rağmen bu hareket devam ederse Moskova Çariçesi'nin memleketini ve reayasını korumak için Tatar askerlerinin tecavüzlerini savunmaya mecbur kalacağını bununla birlikte Çariçenin barışın sonsuza dek devam etmesini ümit ettiğini yazdı (A.DVNS.NMH. d, c. 7: 393-396). Bu mektuba rağmen I. Mahmud, Kırım Hanı'nın İran seferini iptal etmemiş fakat Rusya ile sorun 
yaşamak istemediğinden dolayı da Kırım Hanı'na Rusya ile yapılan barış antlaşmasına uygun hareket edilmesini, Moskov sınırlarına girilmemesini, Rus topraklarının talan edilmemesini ve İslam topraklarına dert, sıkıntı yaratacak durumdan sakınılmasını emretmiştir (Cebecioğlu, Satar, Küçükbaltacıoğlu, Atik, Dilber, Yekeler, Köse, Gurulkan, Gündoğdu, 2013: 44). Fakat bu emirler Rusya ile savaşı engelleyememiştir.

Rusya 1735'te, Kırım Hanı'nın, Kırım, Rus ve Osmanlılar arasında sahipliği tartışmalı olan ama kendisinin olarak kabul ettiği, Kabartay üzerinden Rus sınırlarını ihlal ederek, Kafkas ötesine sefer düzenlemesini savaş nedeni sayarak, Kırım'a savaş açtı (Anisimov, 2002: 273). General M.í. Leontiev önderliğinde 1735 yılının sonbaharında Kırım'a sefer düzenleyen Ruslar, sefer hazırlıklarının tam olarak yapılmamasından ve mevsimin uygun olmamasından dolayı başarısız olarak geri çekilmek zorunda kaldı. Osmanlılara karşı savaş resmî olarak, 1736 yılının ilkbaharında ilan edildi (Kazakov, Nekrasov, 1957: 375). Savaş hazırlıkları yapılana kadar da Osmanlı Devleti'ni kuşkulandırmamak adına, Osmanlı Devleti'nin rahatsızlık duyarak kendisine yönelttiği şu sorulara; Rus askerlerinin Tatar sınırlarına girmeleri sırasında Rusya'ya tabii olan Zaporoje Kazaklarının Nogaylara saldırmaları, Çerakese'ye (Çerkezlere) yakın Ten (Don) Nehri yakınlarında Moskov askerînin toplanmasının nedeni ve Kırım Hanı'nın Dağıstan üzerinden İran'a giderken o taraflarda olan Rus generalinin muamelesi konusunda İstanbul'daki elçi vekili vasıtasıyla cevaplar verildi. Birinci soruya cevap olarak Kırım Tatarlarının İran'a hareketleri sırasında Kırım Hanının barış şartlarına uymayıp dostluğa aykırı olarak Moskova Hükümetine ait olan yerlerden geçmesi konusu daha önce ayrıntılı olarak açıklanmış olmasına rağmen Moskova Çariçesi buna rağmen dostluğa sadık olarak tekrar şu açıklamalarda bulunur: Han Hazretlerinin barışa aykırı olarak İran'a gidip gelmeleri sırasında Tatar taifesinden birçok hareket ve saldırılar olduğundan, bu hareketleri engellemek için sınırlarda bulunan Rus askerî Tatar taifesinin arazisine girdi. Ancak Çariçe Osmanlı Devleti ile olan barışı ve dostluğu korumak arzusunda olduğundan Han Hazretlerinin geri döndüğü duyulduktan sonra askerlerini Moskova sınırlarına çekti. Bu olay sırasında Zaporoje Kazaklarının olay çıkarttığı yönünde Osmanlı Devleti'nin bildirdiği durum doğru değildir. Çünkü Zaporoje Kazakları öteden beri Moskova Devleti'ne bağlıdırlar ve bu hareket sırasında o taraflarda olmayıp meskenlerinde kendi hallerinde bulunmuşlardır.

İkinci soruya verilen cevapta Çerkez'e yakın Don Suyu yakınlarında toplanan askerlerimiz için Osmanlı Devleti'nin kötü düşünmesi doğru değildir. Çünkü zikr olunan askerîmiz, Moskova Çariçesinin devamlı bildirdiği üzere Leh durumuna ara verildikten sonra adet olduğu üzere o taraflarda olan Moskova sınırlarındaki kışlaklarına dönmüşlerdir.

Üçüncü soruya cevap olarak ise Han Hazretlerinin Moskova sınırlarından geçerken Moskova generalinden dostane muamele olunup yiyecek, azık ve hayvanlar verildiğine dair haberlere güvenilmiyor. Han Hazretleriyle o taraflarda 
olan durum Moskova'nın henüz bilgisi dâhilinde olmadığı için bu durum uzun uzadıya anlatılmamıştır. Olayla ilgili bilgiler alındıktan sonra İstanbul'a ayrıntılı olarak bilgiler verileceği belirtildi (BOA, Cevdet Hariciye, Belge No: 7685). İstanbul'da Osmanlı Devleti'ni oyalamak adına bu cevaplar verilirken yukarıda da belirtildiği üzere Rusya savaş hazırlıklarını tamamladıktan sonra 1736 ilkbaharında savaş açtı. Rusya Başvekili Osterman, Nisan 1736'da Osmanlı Sadrazamına uzun bir mektup gönderip, savaşın sorumlusu olarak Osmanlı Devleti ve Kırım Hanlığını gösterdi.

Osterman, gönderdiği uzun mektupta ülkesinin Osmanlı Devleti ile yaptığı antlaşmalara sadık kaldığını bunun Osmanlı tarafından bilinmesine rağmen Osmanlı Devleti'nin sebep olmaksızın İstanbul Antlaşması'nı bozarak savaş açtığını, Prut Nehri tarafında yapılan antlaşmayla Rus Devleti'ne bağlı olan Azak Kalesi'nin Osmanlı Devleti'ne verildiğini, bu antlaşmadan sonra imzalanan Edirne Antlaşması sonrasında Tatar taifeleri ile Azak Paşalarının hemen hemen her yıl Rus topraklarına ve Ruslara tabii Kazaklar ve Kalmuklar üzerine saldırıp kimilerini öldürüp kimilerini esir alarak yağmalarda bulunduklarını ifade etti. Çar Petro'nun saldırıların durdurulması ve zararların karşılanması için yazdığı dostça mektuplara rağmen saldırıların her yıl tekrarlandığını yazdı. İran'da çıkan ihtilal sırasında yaşanan karışıklıklarda Rus tüccarlarının zarar gördüklerini, Çar Petro'nun Rus tüccarlarına zarar verenleri cezalandırmak için Hazar kıyılarına sefer yaptığını, Osmanlı Devleti'nin Rus tüccarlarına saldıran Lezkileri korumakla dostluğa aykırı davrandığını söyledi. Moskova Devleti'nin İran'ın tamamen yıkılmasını engellemek adına hareket ettiğini, Hazar Denizi kıyılarının korunmasına özen gösterirken, Osmanlı Devleti ile olan dostluğa sadık kaldığını, Osmanlı Devleti ile İran'ın paylaşımı için yapılan anlaşmaya Osmanlı Devleti'nin uymayarak İran topraklarına saldırdığını ifade etti. Bu sebeple Moskova Devleti'nin kendisine zarar gelebileceğini düşündüğü için Şirvan ve Gürcistan'a ordu gönderdiğini, bunun Osmanlı Devleti tarafından Rusya'nın İran ile gizlice anlaşıp bölgeyi elde etmek niyetinde olduğu şeklinde algılandığını, oysaki böyle bir düşüncelerinin olmadığını hatta bu bölgedeki sorunlardan kurtulmak için eskiden beri İran arazisi olan Hazar sahilindeki topraklardan askerlerini çektiğini, İran ile bu toprakların sonsuza kadar kendilerinde kalmaları ve Osmanlı Devleti ile yapacakları anlaşmalarda Moskova Çariçesinin isminin geçmesi şartıyla bu toprakları bıraktıklarına dair anlaşma yaptıklarını belirtti. Ancak Osmanlı Devleti'nin İran'a bırakılan arazileri almak için harekete geçtiğini, bu arada Rusya'ya bağlı yerleri basıp, halkına zarar verdiğini, Fetih Giray'ın Tatar ve Osmanlı askerleriyle İran'daki Moskova arazisine ve uzun zamandan beri Dağıstan'daki Moskova'ya bağlı araziye girdiklerini, bu durumun İstanbul'daki elçimiz vasıtasıyla duyurulduğunu, buna rağmen Moskov Devleti'ne bağlı yerlere ve Don Kazaklarına saldırıların devam ettiğini yazdı 1734 senesinde de Azak askerleri, Kırım, Kuban ve Nogay Tatarları, Moskov arazisine saldırıp, Kazaklardan bir kısmını öldürüp bir kısmını da esir aldıklarını, barışa aykırı yapılan bu saldırılar karşısında Moskov Çariçesinin halkını korumaya gücünün olduğunu, bu saldırılara 
tahammülün zor olduğunu bildirdi. Moskov sınırlarına saldırıların bunlarla sınırlı olmadığını, 1735 senesinde Kırım Hanı'nın 80 bin kişilik Tatar askerîyle İran'a teslim edilen araziye girdiğini bu konuya dair yapılan uyarıları Sadrazam Ali Paşa'nın dikkate almadığını ve İstanbul'daki elçimize Dağıstan halkının Osmanlı Devleti'nin halkı olduğunu iddia ettiğini, bu durum üzerine Moskov Çariçesinin topraklarını korumak için gerekli tedbirleri almaya mecbur olduğunu yazdı. Bununla birlikte İstanbul'daki elçileri vasıtasıyla bu sorunu dostça çözmeye çalıştığını, fakat Kırım Hanı Tatar ve Nogay askerleriyle Moskov Devleti'ne bağlı Dağıstan arazisine girerek zararlar verip esir aldıklarını, bu ana kadar Moskov Çariçesinin ısrarla dostça yaklaşımına karşılığın gelmediğini, Kırım Hanı'nın dostluğa aykırı olarak yaptığı bu seferden dönüşü sırasında bir miktar Moskov askerînin sınıra yakın bölgede tutulmasına mecbur kalındığına, Kırım Hanının dönüşünün haber alınması sonrasında bu askerlerin kendi sınırlarına döndüklerini, bu durumun İstanbul'daki elçimiz vasıtasıyla bildirmiş olmamıza rağmen dostane bir çare bulunmadığını bildirdi. Sonrasında Osmanlı Devleti'nin Babadağ'ında asker topladığını, Kırım Han'ın da birçok askerle Moskova sınırlarında olduğunu, elçilerinin alışılmış olan Çariçenin ünvanıyla dostane sunduğu dilekçelerin kabul edilmediğini, Osmanlı Devleti'nin böyle düşmanca tutumundan sonra, Moskova Devleti'nin anası Çariçenin, kanun ve din gereği kendi halkını korumak için ordusunun bir kısmını Osmanlı Devleti'nin üzerine göndermeye mecbur kaldığını söyledi. Çariçenin tembihi üzerine durumun Osmanlı Sadrazamına bildirildiğini, Moskova Çariçesinin kendisini koruması için silahlanmağa mecbur kaldığını, fakat bu harekete çok arzulu olmadığını, dostluğu korumak ve eskisi gibi güvenliği sağlayarak, barış sözleşmesi hazırlamak adına bunu yaptığını, bundan dolayı Moskova Çariçesi, Osmanlı Devleti eğer barış yapma niyetiyle sınırlara elçiler gönderirse kendisinin de elçiler göndermeye hazır olduğunu yazdı. Mektubun sonunda iki devlet halkının rahat ve huzur içinde olması için bir an önce dostluğu sağlamlaştırmak için barışı yenileme konusunda Moskova Çariçesinin dostça uğraşı içinde olduğu Osmanlı Devleti tarafından da bilindiğini, söylendiği üzere Moskova Çariçesi, devletini koruma adına böyle davranmak zorunda kaldığını, Osmanlı Devleti dostça yazılan bu mektuba her ne şekilde karar verirse versin, tüm milletler arasında geçerli olan kurallar gereği, İstanbul'daki kapı kethüdasının eşyası ve hizmetkârlarının yanına adamlar vererek Moskova sınırlarına emniyetli bir şekilde gönderilmesini istedi (A.DVNS.NMH.d, c. 7: 460-471).

Rusya barışa aykırı hareket edenin Kırım Hanlığı ve Osmanlı Devleti olduğunu iddia ederken Osmanlı Devleti de savaşın suçlusu olarak Rusya'yı görüyordu. Osmanlı devlet adamları Rusların suçlamalarına karşılık cevap olarak şu açıklamalarda bulunuyorlardı. Osmanlı Devleti barış şartlarına uyarken, Rusya'nın buna uymayarak 1711'de Boğdan ve çevresine zarar verdiğini, buna engel olmak adına asker gönderilmesine mecbur kalındığını, Çar (Petro) ve askerleri esir olmuşken, Çarın canını kurtarmak için kaleleri yıkacağı ve Osmanlıdan aldığı arazileri geri vereceği sözünü vermesiyle affedildiğini fakat 
Çarın sözünü tutmamasından dolayı tekrar üzerine asker gönderilmesi kararlaştırılıp Edirne'ye hareket edildiğinde İngiltere ve Nedirland'ın arabuluculuğu ile Çar'ın af dilediği ve iki devlet arasında 25 senelik barış yapılmasına rağmen Rusya'nın buna uymadığı belirtiliyordu. Dahası Çariçe Anna çok eskiden beri Müslümanlar ve Hristiyanlar arasında serbestiyetleri kabul edilen Leh sınırına 70-80 bin asker soktuğu, anlaşmaya aykırı olarak kendi menfaati gereğince bu serbestiyeti kaldırarak Ukrayna ve Podalya'yı dahi zapt etti. Leh sınırı içerisinde Osmanlıya ait kaleler ve arazilere kendi muhafızlarını tayin etti. Azak Kalesine 8 saat mesafede olan Çerkez-Kirman Kalesine top menzili yakınındaki harap kaleye 300 ile 500 arasında asker yerleştirdi. Cephane ve zahire yüklü iki gemi ile Ten Nehrine zahire ve mühimmatla yüklü 8 parça gemi gönderip bundan sonra Azak üzerine saldıracaklarını beyan etti. Çerkez Kirman Hetmanının 500 kişilik askerîyle birlikte Moskov askerînin çetecilik yaptığını, Dağıstan ve Şemhal halkının Müslüman olup Osmanlı Devleti'nin egemenliği altında olmalarına rağmen Moskovlunun bazı mallar vererek Dağıstan ve Şemhal halkını kendi yanına çekti. Bunların kendi reayası olduğunu iddia etti. Moskov ile İran üzerine yapılan antlaşmada Gürcistan halkının Osmanlı idaresi altında olması kabul edilmişken firar eden Tiflis Hanı Hıtan Han ile oğlu Şehsuvar’ı kabul ederek, onlara askerler verip kendi yanına çekmeye çalıştı. Bunlardan başka Osmanlı sınırlarında bulunan Abeş Kazağından birçoğunu kendi tarafına çekerek orada kale binası yapımına başladıklarını tüm bunların anlaşma şartlarına aykırı olduğunu, Osmanlı Devleti kararlı bir şekilde barış şartlarına uymayan İran Şahı Nadir Şah ile mücadele ederken, Kırım Hanı Kaplan Giray'ın vekil tayin ettiği Kalgay Sultan sefere çıktığı zaman savunmasız kalan Ur taraflarındaki Tatar aşiretlerine Kazaklar saldırıp yağmalarda bulunduğu yönünde açıklamalarda bulunuyorlardı. Bir yandan bu açıklamalar yapılırken bir yandan da I. Mahmud, Bucak, Özi, Bender taraflarından İslam topraklarına yapılan saldırılarla ilgili gelen yazılar üzerine Babadağ'ında asker toplaması için Özi Valisi Mehmet Paşa'yı, Azak ve Toprakkalelerin tamiri ve içerisindeki asker, zahireler ve mühimmatların arttırılması için de Kapudan-ı Derya Canım Hoca Mehmet Paşa'yı donanma ile birlikte görevlendirdi. Osmanlı Sadrazamının Osterman'a verdiği cevapta Moskov Devleti savaş ve barıştan hangisini seçerse Osmanlı Devleti'nin de onu seçeceğini, İstanbul'daki kapu kethüdalarının eşya ve adamlarıyla sınıra gönderileceği bildirildi (Aydıner, 2007: 280-285).

Osmanlı Devleti yaşanan gelişmeler üzerine savaşın kaçınılmaz olduğunu görse de, Fransa, İngiltere, Avusturya, Nedirlande (Felemenk) ve Venedik'e mektuplar yazarak öncelikli olarak diplomatik yollarla sorunu çözmeye çalıştı. Ruslarla çıkan savaşın sorumlusunun kendisinin olmadığına dair açıklamalarda bulunup arabuluculuk yapmalarını istedi. İngiltere Kralı gönderdiği mektupta savaşın iki devletin de zararına olacağını, hem Osmanlı Devleti'nde hem de Moskov Devleti'nde olan elçilerine iki devlet arasındaki dostluğun korunması ve sağlamlaştııılması için emirler verdiğini, düşmanlığın kaldırılması düşüncesiyle hareket ettiklerini, iki devletin arasındaki savaşın son bulması ve aradaki 
dostluğun yenilenmesi için iki devlet arasında arabuluculuk yapılacağını bildirdi (A.DVNS.NMH.d, c. 7: 428). Avusturya Başvekili göndermiş olduğu mektupta, Avusturya Devleti'nin Pasarofça Antlaşması'ndan itibaren Osmanlı Devleti başka tarafta savaştığı halde, yapılan anlaşmaya bağıı kaldığını yazdıktan sonra Osmanlı Devleti ile Rusya arasındaki sorunlara dair Ruslardan aldıkları bilgiler doğrultusunda şu açıklamaları yaptı. Tatar, Kazak, Lezki taifelerinin yanı sıra Osmanlı askerleri de barışa aykırı olarak Rus topraklarına saldırıp, esir alınanları ve eşyaları Osmanlı topraklarında sattılar. Moskovlu bu durumu şikâyet etti ve savaşa mecbur kaldı. Düzenli olmayan 80 bin kişilik askerîn dost arazisinden geçerken Rus topraklarına zarar vermeleri muhtemeldir. Avusturya başvekili yaptığı bu açıklamalarla Rusya'nın haklılığını ortaya koymaya çalışırken ülkesinin, Moskovlunun müttefiki olarak bu durumu Osmanlı Devletine bildirdiğini ve bu harekâtın kaldırılmasını ısrarla rica ettiğini yazdı. Moskov Çariçesinin Osmanlı Devleti ile barışı korumak arzusunda olduğunu fakat İran Şahının Osmanlı Devleti'nin Moskov üzerine harekete geçeceğini haber verdikten sonra Moskov Devleti'nin barışa dair ısrarından vaz geçerek kendilerini korumayı tercih ettiğini belirtti. Osmanlı Devleti'nin savaş kararının kendilerini hayrete düşürdüğünü, Moskov Çariçesinin rızasıyla savaşı durdurmak için sadakatle çaba gösterdiklerini, Osmanlı başkentinde olan kapu kethüdasına 3 defa emir gönderildiğini fakat halkın rahatını sakinliğini korumak adına yaptığı girişimlerin aylarca boşuna sürdüğünü bildirdi. Mektubunun sonlarında ise Moskov Devleti ile ittifaklarının Osmanlı Devleti ya da bir başka devlete karşı olmadığını, iki tarafın emniyetinin sağlanması ve topraklarının korunması için yapıldığını ifade etti. Moskov Çariçesinin emniyetin sağlanması durumunda bir an önce barış yapma isteğinde olduğunu, Moskov arazisine yapılan saldırıların aynısının Osmanlı topraklarına yapılması durumunda Osmanlı Devleti'nin de aynı şeyleri düşüneceğini, Nemçe Cesarının hem komşusu olan dostları hem de sadık olan müttefiklerinin arasını bulmak için özen göstereceğini bildirdi (A.DVNS.NMH.d, c. 7: 432-436). Fransa Başvekili Kardinal Flori'nin 3 Mayıs'ta yazdığı mektupta, Fransa'nın Osmanlı Devleti'nin kendisine düşmanlık edenlere karşı kuvveti, yiğitliği ve Allah'ın yardımı ile zafer kazanmasını ümit ettiğini, Moskovlu'nun Kırım ve Azak üzerine taarruz etmelerinin Fransa Kralını tasalandırdığını ve kederlendirdiğini, Fransa ile Osmanlı Devleti arasındaki dostluğun eskisinden daha kuvvetli olması için çalışacağından şüphe edilmemesi gerektiğini bildirdi. 10 Mayıs'ta Osmanlı Devleti’nin yazdığı mektuba da hemen hemen aynı yönde cevap verilerek Allah'ın yardımıyla ve kuvvetiyle Osmanlı Devleti'nin düşmanlarına karşı zafer kazanmasının ümit edildiğini, Moskovlu'nun Kırım ve Azak'a saldırılarının Fransa Kralını kederlendirdiğini, Fransa Kralının Osmanlı Devleti'nin dostu olduğunu ve dostluğu kuvvetlendirmek ve devam ettirmek niyetinde olduğunu bildirdi (A.DVNS.NMH.d, c. 7: 449-450). Nedirlande Devleti'nden gönderilen mektupta; Osmanlı Devleti'nin gönderdiği mektuplardan Osmanlı Devleti'nin Moskov üzerine hareket etmesinin nedenlerinin öğrenildiğini, dost oldukları iki devlet arasında yaşanan savaşın bitmesi ve anlaşmaya uygun davranılması için gerek Osmanlı Devleti gerekse Moskov Devleti'ndeki elçilerine emirler verildiğini, 
savaşın bir an önce bitmesi arzusunda olduklarını, iki devlet arasındaki dostluğun yenilenmesi ve devamlı hale gelmesi için çalışılacağı bildirildi (A.DVNS.NMH.d, c. 7: 450) Venedik'ten gönderilen mektupta İstanbul'daki elçilerine verilen mektuptan Rusya üzerine sefer yapılmasına gerek olan sebeplerin öğrenildiğini, bir an önce düşmanlığa sebep olan nedenlerin ortadan kalkması arzusunda olduklarını, Venedik ve Osmanlı Devleti arasındaki dostluğun sağlamlaşması ve sorunun ortadan kalkması için özenle çalışılacağı sözünü verdi (A.DVNS.NMH.d, c. 7: 451) Osmanlı Devleti'nin gönderdiği mektuplar ve yaptığı girişimler devletin genel bilinenin aksine 18. yüzyılda da denge politikası izlediğinin bir göstergesidir. Fakat bu girişimler iki devlet arasındaki savaşı önleyemedi.

1736 ile 1739 yılları arasında yapılan Rus-Osmanlı Savaşı sırasında Ruslar, 1736 ve 1737'de Kırım'ın içlerine kadar ilerleyip, Akmesçit, Gözleve ve Bahçesaray'ı tahrip ettiler. 1736'da Azak, 1737'de Özü, 1739'da Hotin Kalelerini ele geçiren Ruslar, Boğdan'a girip, Yaş şehrini aldılar. Rusya'nın müttefiki olarak 1737'de Osmanlı Devleti'ne savaş açan Avusturyalılar, savaşın başlarında başarı kazanmalarına rağmen daha sonra Osmanlılar tarafından yenilgiye uğratıldılar ve barış yapmak zorunda kaldılar. Avusturyalıların savaştan çekilmesi, İsveçlilerin Osmanlı Devleti’yle ittifak yaptığı söylentilerinin çıkması ve seferler sırasında çıkan salgın hastalıklar ile iklim şartlarından dolayı önemli kayıpların yaşanması Rusların, Karadeniz yönündeki planlarını gerçekleştiremeden 1739 Belgrat Antlaşması'nı imzalamalarına neden oldu (Beskrovnıy, 1958: 247-257; Masaev, 1997: 91-101; Sanin, 1999: 46-49; Uzunçarşılı, 1995: 250-294).

18 Eylül 1739'da imzalanan Belgrat Antlaşması'nın, 3. maddesiyle; Azak Kalesi yıkılacak ve arazisi tarafsız olarak boş bırakılacaktı. Ruslar, eskiden beri Moskova Devleti'nin toprağı olan Don Nehri'nde olan Çerkaski Adası ile Azak arasında bir kale yapacaktı. ${ }^{6}$ Osmanlı Devleti ise Kuban ile Azak arasında bir kale yapacaktı. Yıkılan Taygan Kalesi'nde de bina yapılmayacaktı. Moskova Devleti, Azak ve Karadeniz'de ticaret ve savaş gemileri yapmayacaktı. Ruslar, bu anlaşmayla Azak Kalesi'ni elde edemedi ama Azak Kalesi'nin yıkılıp arazisinin boş bırakılmasını sağlayarak, bölgede önemli bir tehditten kurtulduğu gibi bölgede Osmanlı Devleti'nin askerî olarak önemli bir üsten mahrum kalmasını sağladı. Rusların, Azak Denizi ve Karadeniz'de savaş gemisi ve ticari gemi yapamayacak olmaları, Karadeniz'e çıkıp ticaret yapma ve Azak Denizi ile Karadeniz'de Osmanlı Devleti'ne karşı askerî rekabet yapabilme düşüncelerini yine gerçekleştiremedikleri anlamına geliyordu.

\footnotetext{
6 İsmail Hakkı Uzunçarşılı, Osmanlı Tarihi adlı çalışmasında Çerkaski Adası ile Azak arasında kale yapacak olan devletin Osmanlılar olduğunu yazar. (Uzunçarşılı, 1995: 293) Rus tarihçiler Oreşkova-Ulçenko, Kazakov-Nekrasov ve Beskrovnıy ise, Çerkaski Adası'nda kaleyi yapacak olanların Osmanlılar değil Ruslar olduğunu yazarlar. (Oreşkova,-Ulçenko, 2006: 35 ; Kazakov- Nekrasov, 1957:392, Beskrovnıy, 1958: 258) Ali ibrahim Savaş'ın “Takrir-i Ahmet Merami Efendi (Azak Muhaddidi Ahmet Merami Efendi'nin 1740/1741 Sınır Tespit Çalışmaları Hakkındaki Raporları)", adlı çalışmasında Ahmet Merami Efendi ile Rus General Repnin arasında geçen konuşmalarda kaleyi yapacak olan devletin Ruslar olduğu açıktır. (Savaş, 1994-1995: 160-162)
} 
Antlaşmanın 5. maddesine göre Osmanlı Devleti'ne bağlı Kırım Tatarları ve diğer Tatar taifeleri ile Ruslara bağlı Kazak ve Kalmuklar arasındaki mücadele son bulacaktı. Osmanlı Devleti'ne bağlı olanlar ile Kırım Tatarları Rus şehir ve kasabalarına akın yapıp zarar vermeyecekler ve esir almayacaklardı. Kırım Tatarlarının, Rus topraklarına yapacakları akınların önlenmesi, Rusya'nın güney topraklarının güvenliğinin sağlanması bakımından oldukça önemliydi.

Antlaşmanın 9. maddesine göre İki devlet arasındaki ticaret, Osmanlıların diğer devletlere tanıdığı şartlar gereğince yapılacaktı. Buna göre Rus tüccarı, Karadeniz'de ticareti Osmanlı reayasına ait gemilerle yapacaklardı. ${ }^{7}$ Rusya savaş öncesindeki Karadeniz'de serbestçe ticaret yapma düşüncesini gerçekleştiremese de Rus tüccarlarının, Osmanlı reayasının gemileriyle ticaret yapmaya başlayacak olmaları da Ruslar adına önemli bir gelişmeydi.

Sonuç olarak Rusya, Çariçe Anna zamanında Karadeniz Devleti olmak için çok önemli hazırlıklar yapmış olmasına ve savaşta başarılar kazanmış olmasına rağmen, Karadeniz Devleti olma hayalini gerçekleştiremedi. Bununla birlikte Rusya, savaş öncesi güney sınırlarını güven altına alma ve Karadeniz'de ticaret yapma düşüncesini, kısmen de olsa gerçekleştirmiş oldu. Yapılan savaşta Rusların Kırım Hanlığı toprakları ve Boğdan'da yaptığı tahribat göz önüne alındığında Rusların askeri olarak güçlendiğini söylemek yanlış olmasa gerekir. Yapılan mücadelede Kırım Hanlığının yaşadığı yenilgiler Hanlığın eski gücünde olmadığını net bir şekilde ortaya koyar. Kırım Hanlığı topraklarında yapılan savaşlar daha sonraki mücadeleler için Rus ordusuna önemli bir tecrübe kazandırmıştır. Savaşı diplomatik yollarla engelleyemeyen Osmanlı Devleti, yapılan savaşta askeri yenilgiler alsa da çok da kötü olmayan bir barış antlaşması imzalamıştır. Bununla birlikte özellikle Azak Kalesi'nin yıkılması kararı bölgede zamanla Osmanlı nüfuzunun azalması ile Rusların daha etkin olmasını sağlaması bakımından önemlidir.

\section{KAYNAKÇA}

Başbakanlık Osmanlı Arşivi, Cevdet Hariciye, Belge No:7685

Başbakanlık Osmanlı Arşivi, Namei Hümayun Defterleri, cilt:7.

Cavid A, (2004). Osmanlı- Rus ilişkileri tarihi (Ahmet Cavit Bey'in Müntehabatı), Haz: A. Baycar, İstanbul:Yeditepe Yayınları.

Anisimov, E, (2002). Anna İoannovna, Moskva.

Beskrovnıy, L.G., (1958). Russkaya armiya i flot v XVIII veke, Moskva.

Bobılev, V.S., (2002). Vneşnyaya politika Rossii epohi Petra I, Moskva.

$\mathrm{Hocl}$, Y. İ., "Sadrıazam Said Mehmet Paşa merhumun İstokholme vuku' bulan sefaretinden avdetinde makam-ı sadarete takdim eylediği takrir', Tarih-i Osmani Encümeni Mecmuası, sene:2.

Kazakov, N. İ. - Nekrasov, G. A. (1957). "Vostoçnaya problema v 1725-1735 gg. Russko-Turetskaya voyna 1735-1739 gg. i vzaimootnoşeniya Rossii s

\footnotetext{
7 Belgrat Antlaşması'nın tüm maddeleri için bkz. (Cavid, 2004: 239-242)
} 
inostrannımi derjavami vo vtoroy polovine 1730-x godov", Oçerki İstorii SSSR Period Feodalizma Rossiya vo Vtoroy Çetverti XVIII v. Narodı SSSR v Pervoy Polovine XVIII v. Moskva.

Cebecioğlu M. Satar S., Küçükbaltacığlu D., Atik V., Dilber S., Yekeler N., Köse

R., Gurulkan K., Gündoğdu R., (2013). Kırım Hanlarına Name-i Hümayun (2 Numaralı Name Defteri), i̇stanbul: Başbakanlık Osmanlı Arşivleri Yayınları.

Kurat, A. N, (1999). Rusya Tarihi, Ankara: Türk Tarih kurumu Yayınevi.

Markova, O. P. (1966). Rossiya, Zakavkaze i mejdunarodnıe otnoşeniya v XVIII Veke, Moskva.

Masaev, M. V., (1997). Prisoedinenie Krıma k Rossii, Simferopol.

Melnikova, i. N., (1948). Borba Rossii s Turtsey v 30-x godah XVIII veka i Ukraina/l Uçenia Zapiski Instituta Slavynovedeniya, T. I, Moskva, Leningrad.

Nagıyev, F., (1997). "Hatman", Türk Diyanet Vakfı İslam Ansiklopedisi, cilt:16, İstanbul: Diyanet Vakfı Yayınları.

Nekrasov, G. A., (1976). Rol Rossii v Evropeyskoy mejdunarodnoy politike 17251739 gg, Moskva.

Oreşkova, S. F.,-Ulçenko, N. Yu., (2006). Rossiya i Turtsiya: Problema formirovaniya granits, Moskva.

Sanin, G. A., (1999). "Problema Çernomorskih prolivov vo vneşnoy politike Rossii XVIII. v.", Rossiya i Çernomorskie prolivı (XVIII-XX stoletiya), Moskva.

Savaş, A. I.., (1994-1995). "Takrir-i Ahmet Merami Efendi (Azak Muhaddidi Ahmet Merami Efendi'nin 1740/1741 Sınır Tespit Çalışmaları Hakkındaki Raporları)”, Belgeler, Cilt: XVI, Sayı: 20, Ankara: Türk Tarih Kurumu Yayınları.

Şulman, E. B., (1963). Russko-Turetskaya voyna 1735-1739 godov i politiçeskaya svyazi Moldavii i Valahii s Rossiey, Moskva.

Tertecel, Adrian, (1999). "1735 Yllında Osmanlı-Rus illişkileri (iki Rus Belgesi)", Türk Dünyası Tarih Dergisi, sayı:192. ss. 57-61.

Uzunçarşılı, I. H., (1995). Osmanlı Tarihi, cilt:IV, 1. Kısım, Ankara: Türk Tarih Kurumu Yayınevi.

Vak'anüvis Subhi Mehmed Efendi (2007). Subhi Tarihi, Sami ve Şakir Tarihleri ile birlikte (Inceleme ve Karşılaştırmalı Metin), Haz: M. Aydıner, İstanbul: Kitabevi Yayınları.

Vernadsky, G, (1936). Political and diplomatic history of Russia, Boston.

Yüksel, S., (2013). "Rusların Karadeniz yönünde yaptıkları ilk yayılma faaliyetleri (18. Yüzyılın Başlarına Kadar)”, Süleyman Demirel Üniversitesi Sosyal Bilimler Dergisi, sayı:28, Isparta: Süleyman Demirel Üniversitesi yayınları, ss.101-116.

Yüksel, S., (2012). "Kuzey savaşları sırasında Rusya'nın Karadeniz'e yönelik faaliyetleri”, Ankara Üniversitesi Dil ve Tarih-Coğrafya Fakültesi Tarih Bölümü Tarih Araştırmaları Dergisi, cilt: 31, sayı: 52, Ankara: Ankara Üniversitesi yayınları, ss. 171-190. 